OPEN ACCESS

Edited by:

Rathinam Arthur James, Bharathidasan University, India

Reviewed by:

Nagarajan $R$

Curtin University, Malaysia, Malaysia

Lucienne Human,

South African Environmental

Observation Network, South Africa

*Correspondence:

Vanessa F. Fonseca

vffonseca@fc.ul.pt

Specialty section:

This article was submitted to

Marine Pollution,

a section of the journal

Frontiers in Marine Science

Received: 26 September 2018

Accepted: 25 February 2019

Published: 13 March 2019

Citation:

Fonseca VF, França S, Duarte B, Caçador I, Cabral HN, Mieiro CL,

Coelho JP, Pereira E and

Reis-Santos P (2019) Spatial Variation

in Mercury Bioaccumulation and Magnification in a Temperate

Estuarine Food Web.

Front. Mar. Sci. 6:117.

doi: 10.3389/fmars.2019.00117

\section{Spatial Variation in Mercury Bioaccumulation and Magnification in a Temperate Estuarine Food Web}

\author{
Vanessa F. Fonseca1*, Susana França1 ${ }^{1}$ Bernardo Duarte ${ }^{1}$, Isabel Caçador ${ }^{1,2}$, \\ Henrique N. Cabral1,3, Cláudia L. Mieiro ${ }^{4,5}$, João P. Coelho ${ }^{4}$, Eduarda Pereira ${ }^{6}$ and \\ Patrick Reis-Santos ${ }^{1,7}$
}

\begin{abstract}
'MARE - Marine and Environmental Sciences Centre, Faculdade de Ciências da Universidade de Lisboa, Lisbon, Portugal, ${ }^{2}$ Faculdade de Ciências da Universidade de Lisboa, Lisbon, Portugal, ${ }^{3}$ Irstea, UR EABX, Cestas, France, ${ }^{4}$ Department of Biology and CESAM, University of Aveiro, Aveiro, Portugal, ${ }^{5}$ Department of Life Sciences, CFE, Calçada Martim de Freitas, University of Coimbra, Coimbra, Portugal, ${ }^{6}$ Department of Chemistry and CESAM, University of Aveiro, Aveiro, Portugal, ${ }^{7}$ Southern Seas Ecology Laboratories, School of Biological Sciences, The University of Adelaide, Adelaide, SA, Australia
\end{abstract}

Estuaries are renown sinks or repositories of contaminants and reflect historical pollution of persistent compounds. In particular, mercury $(\mathrm{Hg})$ contamination is widespread in coastal environments and occurs in both inorganic (THg) and highly toxic organic forms $(\mathrm{OHg})$ with high bioaccumulation potential. Trophic magnification factors have been increasingly used to quantify biomagnification and represent the average rate of change in contaminant concentration throughout a food web. Here, we assessed smallscale spatial variation in $\mathrm{THg}$ and $\mathrm{OHg}$ concentrations, as well as variations in local trophic magnification factors in three segregated areas of the Tejo estuary. Selected sites covered a gradient of contamination from industrial $\mathrm{Hg}$ hotspots to a natural reserve area, and are key nursery areas for multiple fishes. We analyzed concentrations in sediment and biota, representing the entire local food webs. Samples included sediments, primary producers (salt marsh plants), primary consumers (macrobenthic invertebrates) and top consumers (fish muscle and liver), and the trophic web structure was characterized via SIAR mixed-modeling of nitrogen and carbon isotopic ratios. Spatial variation in $\mathrm{Hg}$ concentrations was observed in sediment and biota (but not for all species), with highest concentrations in the area near historical mercury input. $\mathrm{Hg}$ concentrations increased with trophic level, and so did the $\mathrm{OHg}$ fraction (\% of $\mathrm{OHg}$ relative to $\mathrm{THg}$ ), with mean maximum values up to 48.7 and $94.9 \%$ in invertebrates and fish, respectively. Trophic magnification factors were positive for all sites ( $p<0.05$ for all regressions), ranging between 1.56 to 1.76 and 1.78 to 2.47 for $\mathrm{THg}$ and $\mathrm{OHg}$, respectively. Overall, rates of mercury bioaccumulation were similar across sites with variations in biota $\mathrm{Hg}$ concentrations reflecting baseline differences in site environmental levels. Understanding mercury bioaccumulation and magnification in estuarine biota is critical to safeguard the multiple ecologic functions and economic benefits estuaries provide.

Keywords: mercury, trophic transfer, isotopic signature, $\delta^{15} \mathrm{~N}, \delta^{13} \mathrm{C}$, nursery area, Tejo estuary 


\section{INTRODUCTION}

Mercury $(\mathrm{Hg})$ pollution is a prevailing issue worldwide due to the long-distance transport and persistence in the environment of $\mathrm{Hg}$, coupled to the high biomagnification and toxicity potential of this element in animals and humans (Minamata Convention on Mercury, UN treaty 2013). In marine and coastal environments, $\mathrm{Hg}$ occurs in many forms (Gworek et al., 2016). Inorganic Hg $\left(\mathrm{Hg}^{2+}\right)$ is the most common, however, it can be biologically (and chemically) converted to the highly toxic organic form of methylmercury $(\mathrm{OHg})$, that biomagnifies through trophic transfer in marine foods webs (e.g., Baeyens et al., 2003; Chen et al., 2009; Coelho et al., 2013).

Trophic magnification factors (TMF) have been increasingly used to quantify the biomagnification of chemicals in the environment, from legacy-type contaminants (e.g., organochlorines) to emerging chemicals of concern, such as pharmaceutical compounds (e.g., Houde et al., 2008; Liu et al., 2017; Matulik et al., 2017). TMF refers to the average rate of change in contaminant concentrations from diet-to consumer along the trophic web, which differs from classic bioaccumulation assessments based on single predator-prey relationships (Borga et al., 2012). The TMF approach relies on combining bioaccumulation data with a characterization of trophic structure, usually via nitrogen and carbon stable isotope analysis and fractioning. Overall, nitrogen isotopic ratios are indicators of species trophic level given the predictable stepwise $\delta^{15} \mathrm{~N}$ enrichment across trophic levels of consumers (typically $3.4 \%$ ) (Minagawa and Wada, 1984; Post, 2002). On the other hand, carbon isotopic ratios are associated with sources of primary producers in the trophic web (e.g., salt marsh plants, seagrass) and have reduced trophic fractioning throughout trophic levels [ca. $0.4 \%$ following Post (2002)]. Hence, TMF is determined from the slope of a regression between the chemical concentration and trophic level of organisms in the food web. In TMF, slope values above zero are indicative of biomagnification (i.e., TMF $>1$ ), whilst the intercept of the regression reflects the concentration of contaminants at the base of the food web (Borga et al., 2012).

Trophic magnification factors assume that diet is the main exposure route to contaminants, hence trophic level is the main driver for bioaccumulation. However, various confounding factors and uncertainties potentially influence TMF, including differences in species biology and/or ecology (e.g., metabolism, reproductive stage, life-cycle), seasonal and spatial variation in isotopic ratios, as well as other local or ecosystem characteristics such as productivity and physical or chemical parameters (Borga et al., 2012). In fact, Borga et al. (2012) argued that different chemical input among sites within a system, or local hotspots, would be reflected in local food webs and in the variability of TMF at small spatial scales.

Estuaries have been described as sinks or repositories of contamination, reflecting historical contamination of $\mathrm{Hg}$ and $\mathrm{OHg}$, particularly in bottom sediments and plants (e.g., Ridgway and Shimmield, 2002; Canário et al., 2010). These are highly productive ecosystems, with conspicuous environmental variability and habitat complexity, thus providing an appealing natural setting to test small-scale spatial dynamics in $\mathrm{Hg}$ and $\mathrm{OHg}$ bioaccumulation and biomagnification along food webs. Moreover, estuaries have long been preferred areas of human settlement, and are globally threatened by multiple human activities that jeopardize their environmental quality and consequently their many ecological functions (Beck et al., 2001; Kennish, 2002). The Tejo estuary is no exception. Whilst renowned for its importance as a nursery area for multiple commercially important fish species (Vasconcelos et al., 2010; Reis-Santos et al., 2013), it also supports a wide array of economic activities (e.g., industrial and urban development, large shipping and port activities, fishing) (Vasconcelos et al., 2007). This estuarine system is one of the largest estuaries in Europe and is the most impacted along the Portuguese coast, with high levels of $\mathrm{Hg}$ contamination in sediments and water from historical anthropogenic sources (Figuéres et al., 1985; Canário et al., 2005; Cesário et al., 2017). However, there are no published data on $\mathrm{Hg}$ concentration in biota from the Tejo, and we still lack an understanding on small scale variability in $\mathrm{Hg}$ contamination, and how this may underpin local bioaccumulation processes.

In this context, we hypothesize that mercury trophic magnification processes in the Tejo estuary are driven by spatial variability in mercury concentration. Hence, the main goal of this work is to assess small-scale spatial variability in mercury concentrations ( $\mathrm{THg}$ and $\mathrm{OHg}$ ) in sediments, biota, and in trophic magnification processes among segregated nursery areas with different abiotic conditions within a large temperate estuary.

\section{MATERIALS AND METHODS}

\section{Study Area}

The Tejo estuary, a permanently open temperate estuarine system with a surface area of $320 \mathrm{~km}^{2}$, has extensive intertidal mudflats fringed by salt marshes that make up to $40 \%$ of the estuarine area, and play a vital ecological role for numerous invertebrate and fish species (e.g., Fonseca et al., 2010; Duarte et al., 2018). Previous work has identified key segregated nursery areas or important habitats for highly commercial fish species, such as Senegalese sole (Solea senegalensis), European sea bass (Dicentrarchus labrax) or Lusitanian toadfish (Halobatrachus didactylus) (Vasconcelos et al., 2010; Cotter et al., 2013; Reis-Santos et al., 2013); with muscle stable isotope ratios and otolith elemental signatures, among others, demonstrating high site fidelity and restricted intra-estuarine fish movements among segregated nursery areas (Cotter et al., 2013; Tanner et al., 2013; Reis-Santos et al., 2015, 2018).

In terms of mercury pollution, historic contamination has been described in water, sediments and plants of the Tejo estuary, with two areas identified as $\mathrm{Hg}$ hotspots from industrial sources (Cesário et al., 2017) (Figure 1). Consequently, three estuarine areas were sampled based on prior information on species occurrence and abundance, trophic web structure and mercury level contamination (França et al., 2011; Fonseca et al., 2013, 2014; Cesário et al., 2017). Sampled 

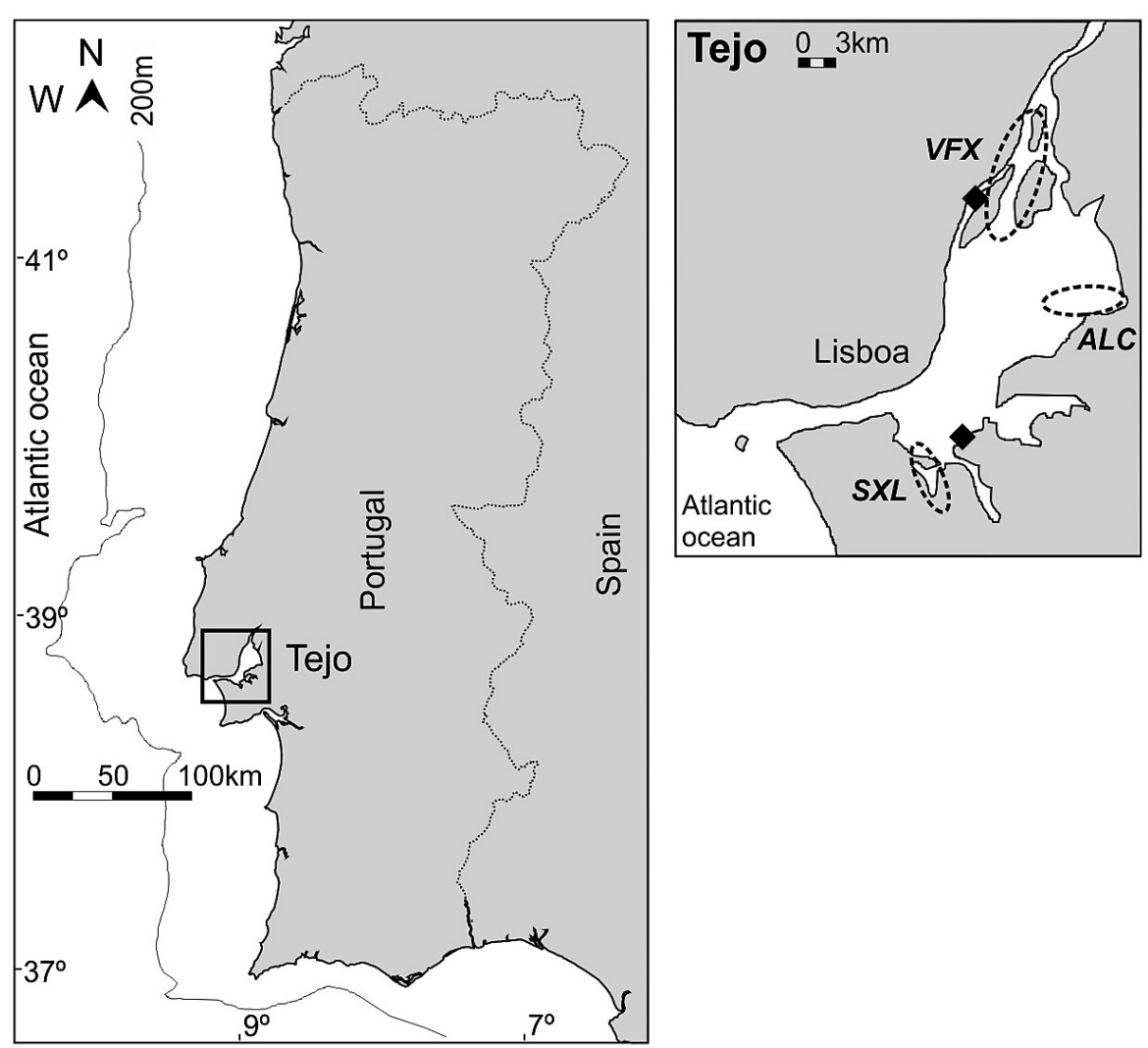

FIGURE 1 | Location of sites sampled within the Tejo estuary (ALC, Alcochete; SXL, Seixal; and VFX, Vila Franca de Xira). Mercury hotspots in the Tejo estuary are also represented (black squares), following Cesário et al. (2017).

areas were selected to reflect an expected gradient of $\mathrm{Hg}$ contamination: with lower $\mathrm{Hg}$ concentrations at a site located in the Nature Reserve of the Tejo estuary (ALC) and distant from $\mathrm{Hg}$ hotspots; an intermediate contaminated site in the bay of Seixal (SXL), south of an $\mathrm{Hg}$ hotspot, and with hydrodynamics and particle exchange dominated by the outer estuary; and a third site with higher Hg levels, in the vicinity of a renowned Hg contamination hotspot (VFX) (Figure 1). All sites are nursery areas for juveniles of commercially important fish species.

\section{Sampling Survey}

Sampling occurred over three consecutive days in late September 2016 and included three to five replicate samples per site of surface sediments, salt marsh plants (Halimione portulacoides, Sarcocornia fruticosa, Spartina maritima), endobenthic and epibenthic macroinvertebrates (Hediste diversicolor, Scrobicularia plana, Carcinus maenas) and fishes (Pomatoschistus microps, $H$. didactylus, $D$. labrax, and $S$. senegalensis). Epibenthic macroinvertebrates and fish were collected with a beam trawl during ebb-tide at each site. Hauls were performed at a constant speed for 5-10 min, and GPS coordinates registered. Collected D. labrax, S. senegalensis, and $H$. didactylus were age $0^{+} / 1$ juveniles from the same yearly cohort; and all $P$. microps (a small sized goby) were c. age $1^{+} / 2$ (Cabral and Costa, 2001;
Leitão et al., 2006; Cotter et al., 2013; Tanner et al., 2013; Reis-Santos et al., 2015). Surface sediments (top 5-8 cm), endobenthic invertebrates (H. diversicolor, S. plana) and primary producers (salt marsh plant species) were collected by hand at low tide in intertidal areas in each site, on the same day and locations of fish sampling. This sediment layer was selected to best represent both the main vertical habitat use of sampled endobenthic macroinvertebrates (Cardoso et al., 2010) and the depth of increased root biomass and root metal retention of salt marsh plants (Duarte et al., 2010). Salinity and water temperature were measured with a multi-parameter probe to characterize and compare the environmental conditions of sampling locations.

Upon collection samples were transported on ice to the laboratory, where individuals were measured and weighed, and appropriate tissues collected (three to five replicates per species and tissue). Tissues with highest accumulation potential were selected, whenever possible, specifically: roots in plant species, digestive gland in C. maenas and S. plana, and muscle and liver in all fish species except for $P$. microps. The latter were processed as whole individuals as were polychaetes $H$. diversicolor due to their small size. Sediment samples were weighted, freeze-dried, ground and sieved through a $1-\mathrm{mm}$ sieve and stored prior to Hg determination. All biological samples were washed with ultra-pure water, prior to being freeze-dried, 
and subsequently ground to a fine powder for dry-weight determination and $\mathrm{Hg}$ analysis.

\section{Mercury Quantification}

Total $\mathrm{Hg}$ in sediments (SedHg) was determined by atomic absorption spectrometry (AAS) with thermal decomposition and gold amalgamation, using a LECO 254 advanced mercury analyser (AMA) (Costley et al., 2000). The accuracy and precision of the analytical methodology for SedHg determinations was assessed by replicate analysis of certified reference materials (CRM), namely Mess-3 (marine sediments). Precision of the method was better than $9 \%(n=17)$, with recovery efficiency of $119.8 \%(n=4)$. Blanks evaluated between each sample were always $<1 \%$ of the SedHg.

Total mercury (THg) determination in biological samples was carried out in three to five replicate samples per species and per site, by AAS, as described for SedHg determination. The accuracy and precision of the analytical methodology for $\mathrm{THg}$ determinations were assessed by daily replicate analysis of certified reference materials, namely ERM-CD200 (seaweed), ERM-CE278k (mussel tissue), Tort-3 (lobster hepatopancreas) and Dorm-4 (fish protein). Precision of the method was always better than $9 \%$, with a recovery efficiency ranging from 85.0 to 105.4\% (Supplementary Table S1).

Organic mercury $(\mathrm{OHg})$ was quantified in three randomly selected samples of each invertebrate and fish species per site (due to limitations in salt marsh root material). Each sample was prepared via duplicate digestion with a mixture of $18 \% \mathrm{KBr}$ in $5 \% \mathrm{H}_{2} \mathrm{SO}_{4}$, followed by extraction into toluene and then backextracted into an aqueous sodium thiosulfate solution (for further details see Válega et al., 2006). Samples were analyzed in the same AMA-LECO 254 instrument, together with the reference materials mentioned above. The precision of the method was always better than $10 \%$, and the extraction efficiency ranged from 75.1 to $86.7 \%$ (Supplementary Table S1).

\section{Data Analysis}

Data were first tested for normality and homogeneity of variances, and where necessary log-transformations were applied to meet these assumptions. Analysis of variance (ANOVA) were followed by a posteriori multiple comparison Tukey tests to assess differences in length and weight of individuals, and in sediment and organisms' mercury concentrations, as well as in abiotic conditions among estuarine sites. Comparison of organisms' mercury concentrations tested differences among all species, and differences among sites per species, whenever individuals occurred in all three sites. Student's $t$-tests were used to test for site differences when species occurred in only two sites (i.e., S. senegalensis). When data was not normally distributed, even following log-transformation (e.g., THg content in $D$. labrax muscle samples and $H$. diversicolor), equivalent non-parametric tests were applied, namely Kruskal-Wallis tests followed by a posterior Dunn's test for multiple comparisons, and Mann-Whitney $U$-tests for two-sample comparisons. In addition, mercury content in fish muscle and liver tissues (D. labrax, S. senegalensis, and H. didactylus) were analyzed separately when assessing species and spatial differences. For simplicity, and due to significantly high correlations between mercury concentration in liver and muscle replicates from the same fish $(r=0.82$ and 0.71 for $\mathrm{THg}$ and $\mathrm{OHg}$, respectively), only results based on liver $\mathrm{Hg}$ content are considered when testing for inter-species comparisons. Correlation analysis (Spearman) were also used to test for a relation between $\mathrm{THg}$ and $\mathrm{OHg}$ content in invertebrates and fish species.

Trophic level (TL) determination was based on $\delta^{13} \mathrm{C}$ and $\delta^{15} \mathrm{~N}$ data, and the methodology described in França et al. (2011), which fully characterized the differential Tejo estuarine trophic webs of ALC and VFX using carbon and nitrogen stable isotope analysis. We used both $\delta^{13} \mathrm{C}$ and $\delta^{15} \mathrm{~N}$, as their combined use enhances food web assessments (Parnell et al., 2010). Briefly, the SIAR mixing model package was used to estimate the relative importance of the primary sources of organic matter to the diet of each consumer. According to Parnell et al. (2010) this Bayesian inference approach allows for dealing with the variability of the input data (i.e., among sources and among samples). In this work, input data relied on França et al. (2011) $\delta^{13} \mathrm{C}$ and $\delta^{15} \mathrm{~N}$ signatures (and standard errors) for all sources and consumer species at the estuarine level. Additionally, trophic enrichment factors (TEF) and uncertainties in model runs followed Post (2002) and were specifically $0.4 \pm 1.3 \%$ for $\delta^{13} \mathrm{C}$ and $3.4 \pm 1.0 \%$ for $\delta^{15} \mathrm{~N}$. Trophic Level for each consumer species was then calculated according to:

$$
\mathrm{TL}=\left(\delta^{15} \mathrm{~N} \text { consumer }-\delta^{15} \mathrm{~N} \text { producer }_{\text {mix }}\right) / 3.4+1
$$

where $3.4 \%$ is the above-mentioned trophic enrichment factor, $\delta^{15} \mathrm{~N}$ consumer is the $\delta^{15} \mathrm{~N}$ signature for each consumer species, and $\delta^{15} \mathrm{~N}$ producer $_{\text {mix }}$ is the proportion of the various primary producers (or mixture of sources of organic matter) that contributed to the consumer's diet (the latter attained through the SIAR model). The TL of salt marsh plants was set at 1 , as they are primary producers (Borga et al., 2012). For H. didactylus, and in the absence of information on local $\delta^{15} \mathrm{~N}$ for this fish species, a TL of 3.95 was defined based on information from FishBase (Froese and Pauly, 2018).

Trophic magnification factors were determined for both $\mathrm{THg}$ and $\mathrm{OHg}$ at site and estuary levels. TMF considered all available measurements along the trophic web, with fish muscle and liver $\mathrm{Hg}$ concentrations analyzed separately. The first step was to regress the logarithm-transformed $\mathrm{THg}$ and $\mathrm{OHg}$ concentrations in organisms ( $\mathrm{Log}[\mathrm{THg}$ or $\mathrm{OHg}]$ ) with $\mathrm{TL}$, as per the following equation:

$$
\log [\mathrm{THg} \text { or } \mathrm{OHg}]=a+b \mathrm{TL}
$$

TMFs or the rate of trophic transfer of THg and OHg along the food web were calculated as the antilog of the regression slopes $(b)$ :

$$
\mathrm{TMF}=10^{b}
$$

Slope values $(b)$ above zero are indicative of biomagnification, with higher values or steeper slopes reflecting increased rates of accumulation over the food web (TMF $>1)$, whereas the intercept $(a)$ of the regression reflects mercury input at the base of the food web (e.g., Borga et al., 2012). Analysis of covariance (ANCOVA), were used to test spatial variability 
in mercury trophic magnification throughout food webs, by evaluating differences in either slope or intercept of multiple regressions of both $\mathrm{THg}$ and $\mathrm{OHg}$. All statistical analyses were performed using $\mathrm{R}$ software, and a significance level of $<0.05$ was considered in all tests.

\section{RESULTS}

Total mercury concentration in sediments ranged between 0.42 and $0.62 \mathrm{mg} \mathrm{kg}^{-1}$ dry weight $(\mathrm{dw})$, and varied among sites $(F=28.6, p<0.001)$, with significantly lower THg levels in ALC (Table 1). Likewise, salinity differed among sites ( $F=11.7, p<0.01$, Table 1$)$ but not temperature. Length and weight of collected organisms was similar among sites (Table 2) (ANOVA and Student's $t, p>0.05$ ), hence no sizeadjustments were applied.

Total mercury concentration along the estuarine trophic web varied between $0.01 \mathrm{mg} \mathrm{kg}{ }^{-1}$ dry weight in the roots of saltmarsh plants (S. fruticosa) and $1.51 \mathrm{mg} \mathrm{kg}^{-1}$ dry weight in fish liver (D. labrax). For fish species, we converted dry weight contamination to $\mathrm{mg} / \mathrm{kg}$ wet weight, to allow comparison of our results with EU regulation EC 1881/2006 (regarding the maximum levels of contaminants in foodstuffs, set in $\mathrm{mg} \mathrm{kg}^{-1}$ wet weight), with maximum THg values of 0.27 and $0.34 \mathrm{mg} \mathrm{kg}^{-1}$ wet weight measured in muscle and liver samples of D. labrax.

Significant differences in $\mathrm{THg}$ load among species were observed $(F=35.16 p<0.001)$, yet $\mathrm{THg}$ did not vary among primary producers (Tukey tests, $p>0.05$ ), nor among

TABLE 1 | Mean (and standard deviation) salinity and temperature measured in each site of the Tejo estuary surveys (ALC, SXL, and VFX); and total mercury concentration (and standard deviation) in the sediment (top 5-8 cm layer) (sediment THg).

\begin{tabular}{lcrr}
\hline & ALC & \multicolumn{1}{c}{ SXL } & \multicolumn{1}{c}{ VFX } \\
\hline Temperature $\left({ }^{\circ} \mathrm{C}\right)$ & $20.9(0.26)$ & $21.8(1.07)$ & $21.58(0.47)$ \\
Salinity & $20.8(1.64)$ & $29.12(0.12)$ & $13.29(4.54)$ \\
Sediment $\mathrm{THg}(\mathrm{mg}$ & $0.43(0.02)$ & $0.55(0.05)$ & $0.52(0.01)$
\end{tabular}

macroinvertebrate species (Tukey tests, $p>0.05$ ). THg was also similar across fish species, except for $S$. senegalensis, which had significantly lower $\mathrm{THg}$ concentrations than remaining fish and invertebrate species (Tukey tests, $p<0.05$ ). Notwithstanding, an increasing trend in $\mathrm{THg}$ from primary producers to consumers was evident (Figure 2), with mean $\mathrm{THg}$ ranging from 0.03 to $0.15 \mathrm{mg} \mathrm{kg}^{-1} \mathrm{dw}$ in primary producers; from 0.20 to $0.47 \mathrm{mg}$ $\mathrm{kg}^{-1} \mathrm{dw}$ in primary consumers; and from 0.15 to $1.03 \mathrm{mg} \mathrm{kg}-1$ $\mathrm{dw}$ in fish tissues (Figure 2).

Regarding spatial variation of $\mathrm{THg}$ per species, highest concentrations were generally observed in organisms from ALC and VFX. In fact, organisms from SXL presented significantly lower THg values when compared to individuals from ALC and VFX [specifically, invertebrates $H$. diversicolor $(H=11.68$ $p<0.001)$, C. maenas $(F=10.56, p<0.01)$, and fish $P$. microps $(F=25.28, p<0.01)$ and $D$. labrax muscle samples $(H=7.58 p<0.05)]$. However, no significant differences among sites were observed for $\mathrm{THg}$ in saltmarsh plants (H. portulacoides and S. fruticosa, $F<2.27, p>0.05$ ), in the bivalve $S$. plana $(F=1.94, p>0.05)$, in $D$. labrax liver samples $(F=0.957, p>0.05)$, and in liver and muscle of S. senegalensis (Student's $t<2.04, p>0.05$ ).

Mean organic mercury concentrations ranged from 0.01 to $0.23 \mathrm{mg} \mathrm{kg}^{-1}$ dry weight in invertebrates and from 0.11 to $0.70 \mathrm{mg} \mathrm{kg}^{-1}$ dry weight in fish (Figure 3). OHg content also differed among species $(F=24.54, p<0.01)$, with significantly lower values in $H$. diversicolor (Tukey tests, $p<0.05$ ), whilst highest values were observed in D. labrax (Tukey tests, $p<0.05$ ), although with $\mathrm{OHg}$ levels comparable to P. microps and $H$. didactylus (Figure 3). An increasing trend in $\mathrm{OHg}$ concentrations along trophic levels was evident, despite some overlap between $\mathrm{OHg}$ values in invertebrate and fish species. $\mathrm{OHg}$ burden in C. maenas was comparable to all fish species, except D. labrax (Tukey tests, $p>0.05$ ), whilst OHg content in S. senegalensis was comparable to S. plana (Tukey tests, $p>0.05$ ). Likewise, the organic mercury fraction (\% of $\mathrm{OHg}$ relative to $\mathrm{THg}$ ) increased with trophic level, with mean values for invertebrate species ranging from 8.87 to $48.7 \%$ in invertebrate species (H. diversicolor and C. maenas, respectively), and from 63.7 to $94.9 \%$ in fish (H. didactylus).

TABLE 2 | Mean (and standard deviation) of length ( $L t$ in $\mathrm{cm}$ ), and weight $(\mathrm{Wt}$ in $\mathrm{g}$ ) of invertebrates and fish sampled per estuarine site (ALC, SXL, and VFX).

\begin{tabular}{|c|c|c|c|c|c|c|c|}
\hline & \multicolumn{2}{|c|}{ ALC } & \multicolumn{2}{|c|}{ SXL } & \multicolumn{2}{|c|}{ VFX } & \multirow[b]{2}{*}{ TL } \\
\hline & Lt (cm) & Wt (g) & Lt (cm) & Wt (g) & Lt (cm) & Wt (g) & \\
\hline S. plana & $3.84(0.18)$ & $6.91(1.31)$ & $3.64(0.45)$ & $6.10(2.58)$ & $3.52(0.31)$ & $5.73(1.41)$ & 1.51 \\
\hline H. diversicolor & & $1.77(0.75)$ & & $1.43(0.88)$ & & $1.86(0.33)$ & 2.14 \\
\hline C. maenas & $4.91(0.51)$ & $29.3(7.97)$ & $4.74(0.35)$ & 28.32 (6.58) & $4.62(0.65)$ & $26.64(9.05)$ & 2.50 \\
\hline S. senegalensis & $14.2(2.60)$ & $31.7(16.1)$ & & & $14.2(3.94)$ & $33.28(17.64)$ & 3.78 \\
\hline H. didactylus & & & 16.5 (2.33) & $78.4(27.2)$ & & & 3.95 \\
\hline D. labrax & $12.4(1.24)$ & $18.4(4.15)$ & $12.7(4.66)$ & $24.4(6.59)$ & $10.9(4.95)$ & $19.35(7.52)$ & 3.38 \\
\hline
\end{tabular}

Trophic level (TL) determined via SIAR mixed modeling is also shown. 


\section{Salt marsh plants}
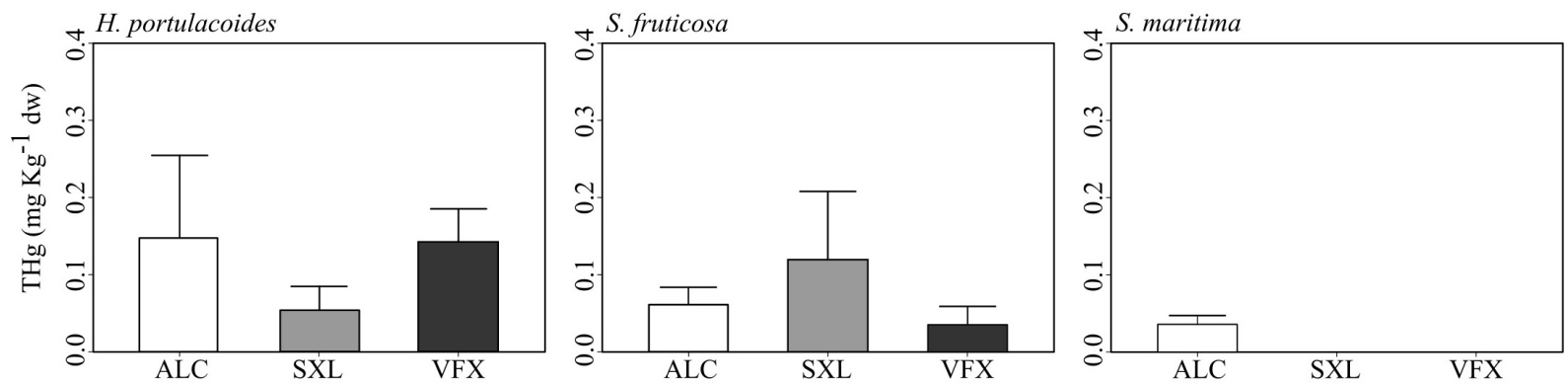

Invertebrates
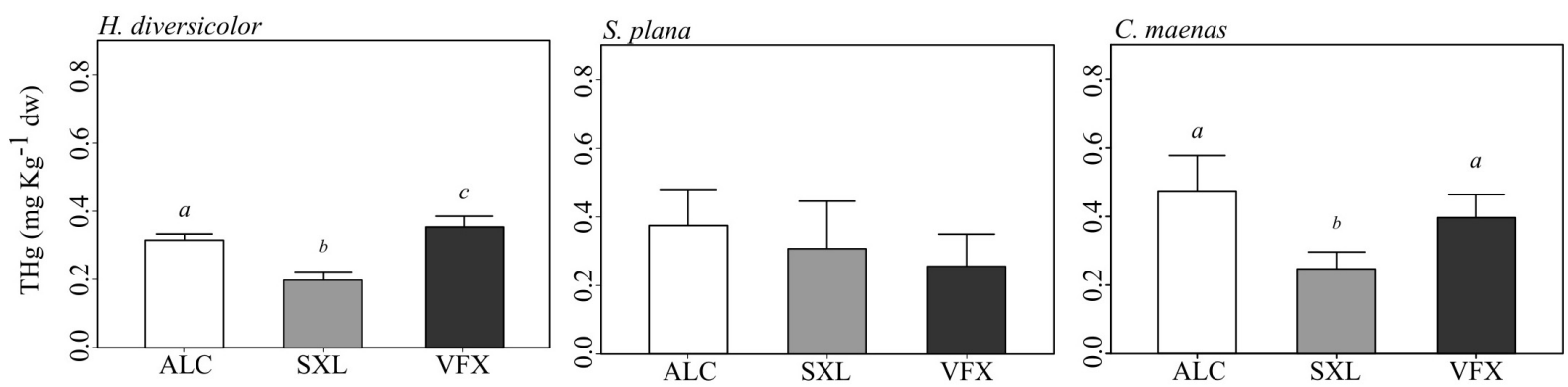

Fish
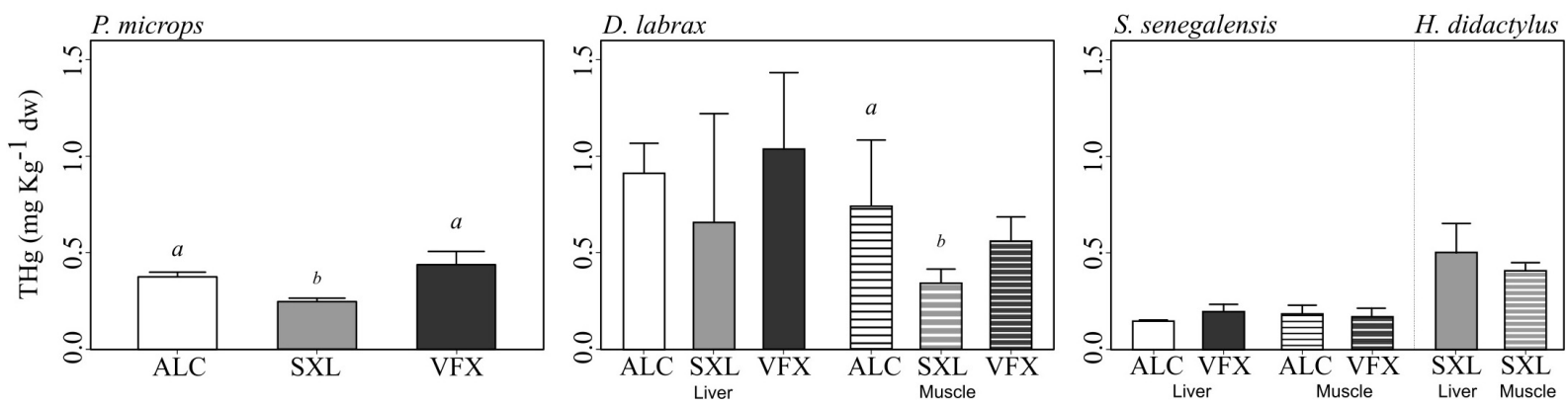

FIGURE 2 | Mean total mercury (THg) concentration ( $\mathrm{mg} \mathrm{kg}^{-1} \mathrm{dry}$ weight) and standard deviation in salt marsh plants, invertebrates and fish species collected in three sites in the Tejo estuary ( $n=3$ to 5 replicate samples per species, tissue and site). Hediste diversicolor and Pomatoschistus microps were analyzed as whole individuals (due to small size), whilst roots, digestive gland, muscle and liver were sampled in plants, other invertebrate and fish species, respectively. In fish, solid bars and line patterns represent liver and muscle concentrations, respectively. Different letters indicate significant differences in THg tissue concentration among sites per species. For trophic levels see Table 2.

Regarding spatial differences in $\mathrm{OHg}$ content per species, concentrations were significantly higher in VFX for $H$. diversicolor, $P$. microps, and $D$. labrax muscle samples $(F>7.56, p<0.05$, Tukey tests, $p<0.05)$. OHg concentrations in muscle of $D$. labrax from ALC also differed from the lower OHg levels measured in SXL (Tukey tests, $p<0.05$ ) (Figure 3).

Overall, a significant positive correlation between $\mathrm{THg}$ and $\mathrm{OHg}$ was observed, when considering both fish liver and muscle samples (rho $>0.58, p<0.05$ ).

Mercury trophic magnification was evident for both mercury forms, with significant regressions of $\log [\mathrm{Hg}$ concentration] with organisms' trophic levels ( $p<0.05$, Table 3 ). TMF values ranged between 1.56 and 1.76 for $\mathrm{THg}$ and between 1.78 and
2.47 for $\mathrm{OHg}$, with fish muscle and liver samples analyzed separately (Table 3 ).

Analysis of covariance did not show significant differences among regressions, in either slopes or intercepts, for both $\mathrm{THg}$ and $\mathrm{OHg}$ (ANCOVA, $p>0.05$ ).

\section{DISCUSSION}

Spatial variability was observed in sediment $\mathrm{THg}$ and reflected the expected gradient across sites, with lower values in ALC, the sampling site located furthest from known $\mathrm{Hg}$ hotspots and well within the Tejo Natural Reserve. Nonetheless, the range of $\mathrm{THg}$ sediment concentrations was not as wide 


\section{Invertebrates}
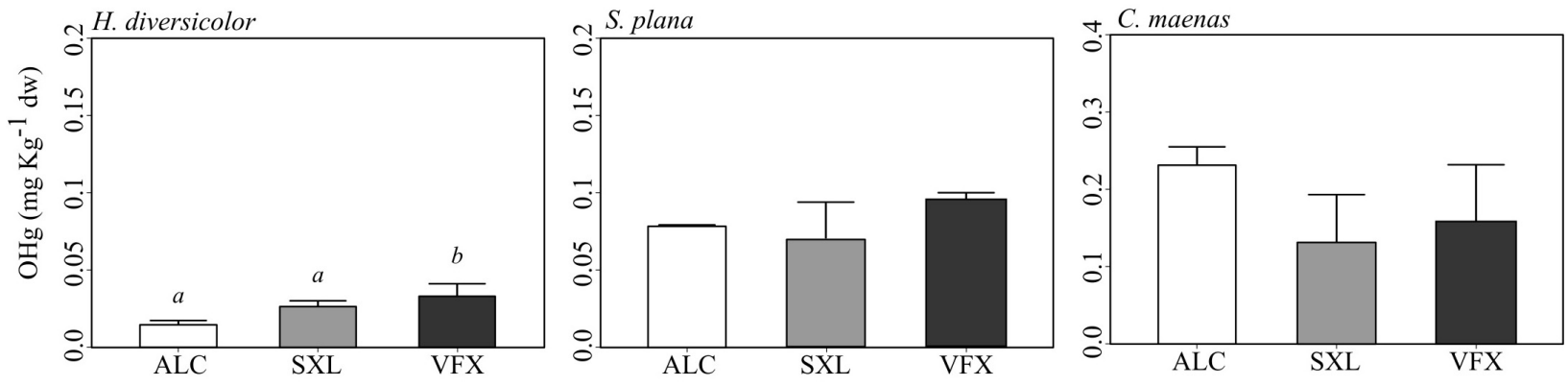

Fish
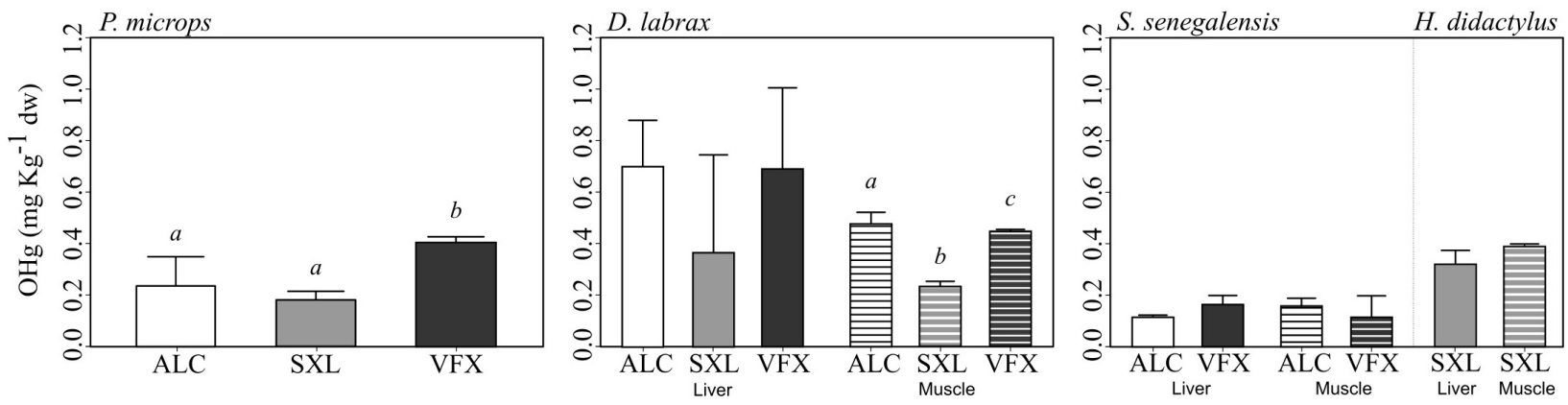

FIGURE 3 | Mean organic mercury (OHg) concentration ( $\mathrm{mg} \mathrm{kg}^{-1}$ dry weight) and standard deviation in invertebrates and fish species collected in three sites in the Tejo estuary ( $n=3$ replicates per species, tissue and site). $H$. diversicolor and $P$. microps were analyzed as whole individuals (due to small size), whilst digestive gland, muscle and liver were sampled in other invertebrate and fish species, respectively. In fish, solid bars and line patterns represent liver and muscle

concentrations, respectively. Different letters indicate significant differences in OHg tissue concentration among sites per species. For trophic levels see Table 2.

as could have been expected given the significant distance between sites (12 to $24 \mathrm{~km}$ ). This may result from natural attenuation of $\mathrm{Hg}$ concentration of surface sediments in $\mathrm{Hg}$ hotspots or by high $\mathrm{Hg}$ transport occurring within the Tejo estuary (Cesário et al., 2018). Tidal influence (which reaches c.80 km landward from the entrance of the estuary) and river discharge (which occurs near the historic $\mathrm{Hg}$ hotspot of VFX) determine the hydrology of the Tejo system (Vaz and Dias, 2014) and therefore influence the anthropogenic Hg signal throughout the estuary, and explain $\mathrm{Hg}$ signals near ALC (Cesário et al., 2016). Overall, present values of THg concentration in sediments were within the range of historic anthropogenic $\mathrm{Hg}$ values measured within the Tejo estuary, although considerably higher THg concentrations (up to $125 \mathrm{mg}$ $\mathrm{kg}^{-1}$ ) have been measured in deeper sediment $(>10 \mathrm{~cm})$ (Cesário et al., 2016, 2017).

Spatial variability in mercury content of estuarine organisms was also observed for some species, namely invertebrates $H$. diversicolor and C. maenas, and fish species P. microps and D. labrax (muscle samples). The variation pattern was similar between $\mathrm{THg}$ and $\mathrm{OHg}$ across invertebrate and fish species, with generally higher values in the area located near an $\mathrm{Hg}$ hotspot (VFX). Nevertheless, lower Hg levels were observed in organisms collected from SXL, where maximum THg values were determined. Differences in mercury bioavailability among sites, in association to the different local abiotic conditions (e.g., salinity, $\mathrm{pH}$, dissolved organic matter) may be the cause for the observed mismatch between mercury concentration in organisms and sediments from SXL (e.g., Mason et al., 1993; Schartup et al., 2015). However, baseline biogeochemical data and knowledge on local mercury fluxes and behavior will be required to further resolve this issue. In addition to varying environmental $\mathrm{Hg}$ concentrations, dietary plasticity can also influence inter-site variation in $\mathrm{Hg}$ accumulation if individuals are able to explore different prey items or temporary peaks in abundance of prey that differ from one area to another (e.g., Ley et al., 1994). This could be the case for predator species $P$. microps, D. labrax, and $H$. didactylus (Thorman and Wiederholm, 1986; Cabral and Costa, 2001; Pereira et al., 2011), or omnivorous species C. maenas (Baeta et al., 2006) and $H$. diversicolor, although the latter may act both as a predator and a deposit-feeder (Scaps, 2002). Nonetheless, considering that ALC and VFX have similar benthic trophic web structures (França et al., 2011), it is more likely that variations in $\mathrm{Hg}$ concentration and bioavailability underpin the observed intersite differences in $\mathrm{Hg}$ bioaccumulation.

Regarding other analyzed species, mercury load did not vary across sites in salt marsh plants, in the bivalve S. plana, or in the senegalese sole $S$. senegalensis. Halophytes are known to retain metals and metalloids, particularly in roots (Duarte et al., 2010), with recent studies evidencing high tolerance and regulation of mercury content in salt marsh species (e.g., Anjum et al., 2016; 
TABLE 3 | Regression analyses of log-transformed total (THg) and organic mercury $(\mathrm{OHg})$ concentrations in estuarine organisms with species trophic level, per site (ALC, SXL, and VFX) and in the Tejo estuary.

\begin{tabular}{|c|c|c|c|c|c|c|}
\hline & $n$ & intercept & slope & $F$ & $p$ & TMF \\
\hline \multicolumn{7}{|l|}{ THg Liver } \\
\hline Estuary & 112 & 1.822 & 0.241 & 67.1 & $<0.001$ & 1.74 \\
\hline ALC & 38 & 1.851 & 0.246 & 19.6 & $<0.001$ & 1.76 \\
\hline$S X L$ & 37 & 1.756 & 0.240 & 34.6 & $<0.001$ & 1.74 \\
\hline VFX & 37 & 1.860 & 0.234 & 16.8 & $<0.001$ & 1.71 \\
\hline \multicolumn{7}{|c|}{ THg Muscle } \\
\hline Estuary & 112 & 1.875 & 0.203 & 57.3 & $<0.001$ & 1.60 \\
\hline ALC & 38 & 1.913 & 0.205 & 16.1 & $<0.001$ & 1.60 \\
\hline SXL & 37 & 1.799 & 0.211 & 34.8 & $<0.001$ & 1.63 \\
\hline VFX & 37 & 1.920 & 0.192 & 13.0 & $<0.001$ & 1.56 \\
\hline \multicolumn{7}{|l|}{ OHgLiver } \\
\hline Estuary & 54 & 1.156 & 0.347 & 25.9 & $<0.001$ & 2.22 \\
\hline ALC & 18 & 1.169 & 0.335 & 4.8 & $<0.05$ & 2.16 \\
\hline SXL & 18 & 1.042 & 0.369 & 18.5 & $<0.001$ & 2.34 \\
\hline VFX & 18 & 1.253 & 0.345 & 10.0 & $<0.01$ & 2.21 \\
\hline \multicolumn{7}{|c|}{$\mathrm{OHg}_{\text {Muscle }}$} \\
\hline Estuary & 54 & 1.209 & 0.317 & 21.7 & $<0.001$ & 2.07 \\
\hline ALC & 18 & 1.146 & 0.331 & 5.1 & $<0.05$ & 2.14 \\
\hline SXL & 18 & 0.988 & 0.393 & 32.1 & $<0.001$ & 2.47 \\
\hline VFX & 18 & 1.510 & 0.251 & 4.6 & $<0.05$ & 1.78 \\
\hline
\end{tabular}

Trophic magnification analyses considered all available measurements ( $n$, number of samples) of THg (including saltmarsh plants, invertebrates and fish species), and $\mathrm{OHg}$ (invertebrates and fish species), with separate analyses considering mercury determination in liver and muscle tissues of larger fish species.

Cabrita et al., 2018). This could also be related to widespread $\mathrm{Hg}$ transport throughout the estuary, coupled with speciesspecific ecological and physiological traits. At lower trophic levels, species could be reflecting the small gradient in $\mathrm{Hg}$ surface sediment levels, whilst species at higher trophic positions evidenced higher spatial differences due to trophic transfer processes. S. plana and $H$. diversicolor are both sediment-dwelling invertebrates that can behave as deposit feeders (Hughes, 1969; Scaps, 2002), yet showed different $\mathrm{THg}$ and $\mathrm{OHg}$ accumulation patterns. As such, $H$. diversicolor may be using diverse feeding strategies to explore resources as an omnivore or a predator. On the other hand, dissolved and particulate fractions are likely the main driver of $\mathrm{Hg}$ accumulation in S. plana. Coelho et al. (2013) has made similar inferences regarding observed differences in trophic level and $\mathrm{Hg}$ burden between these two species in another coastal system with significant mercury contamination. Lack of occurrence of juvenile S. senegalensis in SXL limited inter-site comparison for this species, given that this site was key to unravel contamination patterns in other fish species.

In terms of mercury trophic transfer, both $\mathrm{THg}$ and $\mathrm{OHg}$ concentrations increased with trophic level, although the rate of $\mathrm{OHg}$ biomagnification was higher, as could be expected (Lawson and Mason, 1998), and evident in the increased proportion of $\mathrm{OHg}$ (\% of $\mathrm{THg}$ ) with increasing trophic level. The slopes or rates of $\mathrm{Hg}$ trophic transfer (i.e., TMF) were within range of a recent meta-analysis on $\mathrm{Hg}$ biomagnification in aquatic food webs worldwide (Lavoie et al., 2013). These authors described spatial differences in trophic magnification slopes with latitude, yet lack of environmental data hindered analysis on the effects of physical and chemical variation on $\mathrm{Hg}$ biomagnification at the ecosystem level. Present results do not allow to address this caveat, since the number of sites was also reduced. In addition, trophic magnification factors did not vary among sites, despite differences in local abiotic features, $\mathrm{Hg}$ input, and observed inter-site variation in $\mathrm{Hg}$ content of some invertebrate and fish species. The most likely cause is widespread transport and potential homogenization of the distribution of $\mathrm{Hg}$ throughout the Tejo estuary, despite the existence of known $\mathrm{Hg}$ hotspots (Cesário et al., 2018). Furthermore, continuous dredging and other port activities occurring in the estuary can promote the resuspension of sediments and the potential increase in transport and availability of mercury throughout the system (Eggleton and Thomas, 2004).

In hindsight, spatial gradient in $\mathrm{Hg}$ concentrations between sampled sites might not be strong enough to influence TMFs. Though recent modeling approaches have explored the potential bias associated with spatial concentration gradients on chemical biomagnification and TMF in aquatic ecosystems (Kim et al., 2016; Mackay et al., 2016), reported spatial variation in TMFs refer only to wider geographical areas (e.g., Baeyens et al., 2003; Borga et al., 2012).

Uncertainties associated with stable isotopes analysis and trophic level determination could also influence biomagnification assessment and TMF calculations (Borga et al., 2012). Nevertheless, trophic levels were similar to those reported elsewhere for the same species (e.g., Pasquaud et al., 2010; Coelho et al., 2013), and the SIAR mixed-modeling approach enabled the adequate characterization of food web baselines, as emphasized by Lavoie et al. (2013). Though all sampling took place in consecutive days, spatial and seasonal differences in isotopic signatures are known to occur within estuaries (e.g., França et al., 2011; Green et al., 2012) and could influence the consistency of TMF. Accordingly, we encourage future work exploring seasonal variability in TMFs, given such information will be crucial to underpin potential sources of variability in field biomagnifications assessments (Lavoie et al., 2013).

Overall, results show that $\mathrm{Hg}$ transport and uptake by individuals is ubiquitous in the Tejo estuary, regardless of the low connectivity among nursery areas, and the distance among sites and to Hg hotspots. Noteworthy, mercury concentrations in juvenile fish life stages did not exceed regulatory standards set for contaminants in foodstuffs $\left(0.5 \mathrm{mg} \mathrm{kg}^{-1}\right.$ wet weight following EC 1881/2006). Nevertheless, observed sediment and individual $\mathrm{Hg}$ concentrations fall within the range of concentrations previously linked with deleterious biological effects on vertebrate and invertebrate species (e.g., Long et al., 1995; Depew et al., 2012; Mieiro et al., 2014). Ultimately, anthropogenic emissions of $\mathrm{Hg}$ have been significantly reduced in the last decades (Pacyna et al., 2001), yet ongoing contamination and bioaccumulation across ecosystems persists. In the context of nursery areas, which play a key role in the replenishment of coastal fishery stocks, exploring small-scale variation in estuarine $\mathrm{Hg}$ contamination is key to 
assess potential effects on juvenile biota, and consequent potential long-term implications on the adult coastal fishery stocks targeted for human consumption (e.g., Rochet, 2000; Fonseca et al., 2015).

\section{AUTHOR CONTRIBUTIONS}

VF wrote the main draft of the manuscript, based on ideas conceived by VF and PR-S. All authors contributed ideas and to writing the manuscript. PR-S, BD, and VF designed and implemented the field collections. CM and JC performed the extraction and chemical analyses. SF and VF conducted data analysis. All authors reviewed and approved the final submitted version.

\section{REFERENCES}

Anjum, N. A., Duarte, B., Caçador, I., Sleimi, N., Duarte, A. C., and Pereira, E. (2016). Biophysical and biochemical markers of metal/metalloid-impacts in salt marsh halophytes and their implications. Front. Environ. Sci. 4:24. doi: 10.3389/fenvs.2016.00024

Baeta, A., Cabral, H. N., Marques, J. C., and Pardal, M. A. (2006). Feeding ecology of the green crab, Carcinus maenas (L., 1758) in a temperate Estuary, Portugal. Crustaceana 79, 1181-1193. doi: 10.1163/156854006778859506

Baeyens, W., Leermakers, M., Papina, T., Saprykin, A., Brion, N., Noyen, J., et al. (2003). Bioconcentration and biomagnification of mercury and methylmercury in north sea and scheldt estuary fish. Arch. Environ. Contam. Toxicol. 45, 498-508. doi: 10.1007/s00244-003-2136-4

Beck, M. W., Heck, K. L., Able, K. W., Childers, D. L., Eggleston, D. B., Gillanders, B. M., et al. (2001). The identification, conservation, and management of estuarine and marine nurseries for fish and invertebrates. Bioscience 51, 633-641. doi: 10.1641/0006-3568(2001)051[0633:TICAMO]2.0.CO;2

Borga, K., Kidd, K. A., Muir, D. C., Berglund, O., Conder, J. M., Gobas, F. A., et al. (2012). Trophic magnification factors: considerations of ecology, ecosystems, and study design. Integr. Environ. Assess. Manag. 8, 64-84. doi: 10.1002/ ieam. 244

Cabral, H., and Costa, M. J. (2001). Abundance, feeding ecology and growth of 0-group sea bass, Dicentrarchus labrax, within the nursery areas of the Tagus estuary. J. Mar. Biol. Assoc. UK 81, 679-682. doi: 10.1017/s00253154010 04362

Cabrita, M. T., Duarte, B., Cesario, R., Mendes, R., Hintelmann, H., Eckey, K., et al. (2018). Mercury mobility and effects in the salt-marsh plant Halimione portulacoides: uptake, transport, and toxicity and tolerance mechanisms. Sci. Total Environ. 650(Pt 1), 111-120. doi: 10.1016/j.scitotenv.2018.08.335

Canário, J., Vale, C., and Caetano, M. (2005). Distribution of monomethylmercury and mercury in surface sediments of the Tagus Estuary (Portugal). Mar. Pollut. Bull. 50, 1142-1145. doi: 10.1016/j.marpolbul.2005.06.052

Canário, J., Vale, C., Poissant, L., Nogueira, M., Pilote, M., and Branco, V. (2010). Mercury in sediments and vegetation in a moderately contaminated salt marsh (Tagus Estuary, Portugal). J. Environ. Sci. 22, 1151-1157. doi: 10.1016/s10010742(09)60231-x

Cardoso, I., Granadeiro, J. P., and Cabral, H. (2010). Benthic macroinvertebrates' vertical distribution in the Tagus estuary (Portugal): the influence of tidal cycle. Estuar. Coast. Shelf Sci. 86, 580-586. doi: 10.1016/j.ecss.2009.11.024

Cesário, R., Hintelmann, H., O’Driscoll, N. J., Monteiro, C. E., Caetano, M., Nogueira, M., et al. (2017). Biogeochemical cycle of mercury and methylmercury in two highly contaminated areas of tagus estuary (Portugal). Water Air Soil Pollut. 228:257. doi: 10.1007/s11270-017-3442-1

Cesário, R., Monteiro, C. E., Nogueira, M., O’Driscoll, N. J., Caetano, M., Hintelmann, H., et al. (2016). Mercury and methylmercury dynamics in sediments on a protected area of tagus estuary (Portugal). Water Air Soil Pollut. 227:475. doi: 10.1007/s11270-016-3179-2

\section{FUNDING}

This study had the support of the Fundação para a Ciência e a Tecnologia (FCT) via UID/MAR/04292/2019 and PTDC/MAR-EST/3048/2014, and of the MAR 2020 program via 16-01-04-FMP-0014. PR-S and BD were funded with FCT postdoctoral grants (SFRH/BPD/95784/2013 and SFRH/BPD/115162/2016, respectively).

\section{SUPPLEMENTARY MATERIAL}

The Supplementary Material for this article can be found online at: https://www.frontiersin.org/articles/10.3389/fmars. 2019.00117/full\#supplementary-material

Cesário, R., Mota, A. M., Caetano, M., Nogueira, M., and Canário, J. (2018). Mercury and methylmercury transport and fate in the water column of Tagus estuary (Portugal). Mar. Pollut. Bull. 127, 235-250. doi: 10.1016/j.marpolbul. 2017.11.066

Chen, C. Y., Dionne, M., Mayes, B. M., Ward, D. M., Sturup, S., and Jackson, B. P. (2009). Mercury bioavailability and bioaccumulation in estuarine food webs in the Gulf of Maine. Environ. Sci. Technol. 43, 1804-1810. doi: 10.1021/es80 17122

Coelho, J. P., Mieiro, C. L., Pereira, E., Duarte, A. C., and Pardal, M. A. (2013). Mercury biomagnification in a contaminated estuary food web: effects of age and trophic position using stable isotope analyses. Mar. Pollut. Bull. 69, 110-115. doi: 10.1016/j.marpolbul.2013.01.021

Costley, C. T., Mossop, K. F., Dean, J. R., Garden, L. M., Marshall, J., and Carroll, J. (2000). Determination of mercury in environmental and biological samples using pyrolysis atomic absorption spectrometry with gold amalgamation. Anal. Chim. Acta 405, 179-183. doi: 10.1016/S0003-2670(99)00742-4

Cotter, J. C., Pereira, T. J., Costa, M. J., and Costa, J. L. (2013). Distribution, abundance, population structure and activity of Halobatrachus didactylus in the Tagus estuary (Portugal) and adjacent coastal waters. J. Mar. Biol. Assoc. U. K. 93, 405-412. doi: 10.1017/s002531541100169x

Depew, D. C., Basu, N., Burgess, N. M., Campbell, L. M., Devlin, E. W., Drevnick, P. E., et al. (2012). Toxicity of dietary methylmercury to fish: derivation of ecologically meaningful threshold concentrations. Environ. Toxicol. Chem. 31, 1536-1547. doi: 10.1002/etc. 1859

Duarte, B., Caetano, M., Almeida, P. R., Vale, C., and Cacador, I. (2010). Accumulation and biological cycling of heavy metal in four salt marsh species, from Tagus estuary (Portugal). Environ. Pollut. 158, 1661-1668. doi: 10.1016/j. envpol.2009.12.004

Duarte, I. A., Vasconcelos, R. P., Franca, S., Batista, M. I., Tanner, S., Cabral, H. N., et al. (2018). Short-term variability of fish condition and growth in estuarine and shallow coastal areas. Mar. Environ. Res. 134, 130-137. doi: 10.1016/j. marenvres.2018.01.008

Eggleton, J., and Thomas, K. V. (2004). A review of factors affecting the release and bioavailability of contaminants during sediment disturbance events. Environ. Int. 30, 973-980. doi: 10.1016/j.envint.2004.03.001

Figuéres, G., Martin, J. M., Meybeck, M., and Seyler, P. (1985). A comparative study of mercury contamination in the Tagus estuary (Portugal) and major French estuaries (Gironde, Loire, Rhône). Estuar. Coast. Shelf Sci. 20, 183-203. doi: 10.1016/0272-7714(85)90037-x

Fonseca, V. F., Neill, W. H., Miller, J. M., and Cabral, H. N. (2010). Ecophys.Fish perspectives on growth of juvenile soles, Solea solea and Solea senegalensis, in the Tagus estuary, Portugal. J. Sea Res. 64, 118-124. doi: 10.1016/j.seares.2009. 10.007

Fonseca, V. F., Vasconcelos, R. P., Franca, S., Serafim, A., Lopes, B., Company, R., et al. (2014). Modeling fish biological responses to contaminants and natural variability in estuaries. Mar. Environ. Res. 96, 45-55. doi: 10.1016/j.marenvres. 2013.10.011 
Fonseca, V. F., Vasconcelos, R. P., Gamito, R., Pasquaud, S., Gonçalves, C. I., Costa, J. L., et al. (2013). Fish community-based measures of estuarine ecological quality and pressure-impact relationships. Estuar. Coast. Shelf Sci. 134, 128-137. doi: 10.1016/j.ecss.2013.02.001

Fonseca, V. F., Vasconcelos, R. P., Tanner, S. E., França, S., Serafim, A., Lopes, B., et al. (2015). Habitat quality of estuarine nursery grounds: integrating nonbiological indicators and multilevel biological responses in Solea senegalensis. Ecol. Indic. 58, 335-345. doi: 10.1016/j.ecolind.2015.05.064

França, S., Vasconcelos, R. P., Tanner, S., Maguas, C., Costa, M. J., and Cabral, H. N. (2011). Assessing food web dynamics and relative importance of organic matter sources for fish species in two Portuguese estuaries: a stable isotope approach. Mar. Environ. Res. 72, 204-215. doi: 10.1016/j.marenvres.2011.09.001

Froese, R., and Pauly, D. (2018). FishBase. World Wide Web Electronic Publication. Available at: www.fishbase.org (accessed October 2018).

Green, B. C., Smith, D. J., Grey, J., and Underwood, G. J. (2012). High site fidelity and low site connectivity in temperate salt marsh fish populations: a stable isotope approach. Oecologia 168, 245-255. doi: 10.1007/s00442-011-2077-y

Gworek, B., Bemowska-Kalabun, O., Kijenska, M., and Wrzosek-Jakubowska, J. (2016). Mercury in marine and oceanic waters-a review. Water Air Soil Pollut. 227:371. doi: 10.1007/s11270-016-3060-3

Houde, M., Muir, D. C., Kidd, K. A., Guildford, S., Drouillard, K., Evans, M. S., et al. (2008). Influence of lake characteristics on the biomagnification of persistent organic pollutants in lake trout food webs. Environ. Toxicol. Chem. 27, 2169-2178. doi: 10.1897/08-071.1

Hughes, R. N. (1969). A study of feeding in Scrobicularia plana. J. Mar. Biol. Assoc. UK 49, 805-823. doi: 10.1017/S0025315400037309

Kennish, M. J. (2002). Environmental threats and environmental future of estuaries. Enviro. Conserv. 29, 78-107. doi: 10.1017/s0376892902000061

Kim, J., Gobas, F. A., Arnot, J. A., Powell, D. E., Seston, R. M., and Woodburn, K. B. (2016). Evaluating the roles of biotransformation, spatial concentration differences, organism home range, and field sampling design on trophic magnification factors. Sci. Total Environ. 55, 438-451. doi: 10.1016/j.scitotenv. 2016.02.013

Lavoie, R. A., Jardine, T. D., Chumchal, M. M., Kidd, K. A., and Campbell, L. M. (2013). Biomagnification of mercury in aquatic food webs: a worldwide meta-analysis. Environ. Sci. Technol. 47, 13385-13394. doi: 10.1021/es403103t

Lawson, N. M., and Mason, R. P. (1998). Accumulation of mercury in estuarine food chains. Biogeochemistry 40, 235-247. doi: 10.1023/A:1005959211768

Leitão, R., Martinho, F., Neto, J. M., Cabral, H., Marques, J. C., and Pardal, M. A. (2006). Feeding ecology, population structure and distribution of Pomatoschistus microps (Krøyer, 1838) and Pomatoschistus minutus (Pallas, 1770) in a temperate estuary, Portugal. Estuar. Coast. Shelf Sci. 66, 231-239. doi: $10.1016 /$ j.ecss.2005.08.012

Ley, J. A., Montague, C. L., and Mclvor, C. C. (1994). Food habits of mangrove fishes: a comparison along estuarine gradients in northeastern Florida Bay. Bull. Mar. Sci. 54, 881-899.

Liu, S., Zhao, H., Lehmler, H. J., Cai, X., and Chen, J. (2017). Antibiotic pollution in marine food webs in laizhou bay, north China: trophodynamics and human exposure implication. Environ. Sci. Technol. 51, 2392-2400. doi: 10.1021/acs.est. 6b04556

Long, E. R., MacDonald, D. D., Smith, S. L., and Calder, F. D. (1995). Incidence of adverse biological effects within ranges of chemical concentrations in marine and estuarine sediments. Environ. Manag. 19, 81-97. doi: 10.1007/BF02472006

Mackay, D., Celsie, A. K. D., Arnot, J. A., and Powell, D. E. (2016). Processes influencing chemical biomagnification and trophic magnification factors in aquatic ecosystems: implications for chemical hazard and risk assessment. Chemosphere 154, 99-108. doi: 10.1016/j.chemosphere.2016.03.048

Mason, R. P., Fitzgerald, W. F., Hurley, J., Hanson, A. K. Jr., Donaghay, P. L., and Sieburth, J. M. (1993). Mercury biogeochemical cycling in a stratified estuary. Limnol. Oceanogr. 38, 1227-1241. doi: 10.4319/lo.1993.38.6.1227

Matulik, A. G., Kerstetter, D. W., Hammerschlag, N., Divoll, T., Hammerschmidt, C. R., and Evers, D. C. (2017). Bioaccumulation and biomagnification of mercury and methylmercury in four sympatric coastal sharks in a protected subtropical lagoon. Mar. Pollut. Bull. 116, 357-364. doi: 10.1016/j.marpolbul. 2017.01.033

Mieiro, C. L., Dolbeth, M., Marques, T. A., Duarte, A. C., Pereira, M. E., and Pacheco, M. (2014). Mercury accumulation and tissue-specific antioxidant efficiency in the wild European sea bass (Dicentrarchus labrax) with emphasis on seasonality. Environ. Sci. Pollut. Res. 21, 10638-10651. doi: 10.1007/s11356014-3053-y

Minagawa, M., and Wada, E. (1984). Stepwise enrichment of $15 \mathrm{~N}$ along food chains: further evidence and the relation between $\delta 15 \mathrm{~N}$ and animal age. Geochim. Cosmochim. Acta 48, 1135-1140. doi: 10.1016/0016-7037(84)90 204-7

Pacyna, E. G., Pacyna, J. M., and Pirrone, M. (2001). European emissions of atmospheric mercury from anthropogenic sources in 1995. Atmos. Environ. 35, 2987-2996. doi: 10.1016/S1352-2310(01)00102-9

Parnell, A. C., Inger, R., Bearhop, S., and Jackson, A. L. (2010). Source partitioning using stable isotopes: coping with too much variation. PLoS One 5:e9672. doi: 10.1371/journal.pone.0009672

Pasquaud, S., Pillet, M., David, V., Sautour, B., and Elie, P. (2010). Determination of fish trophic levels in an estuarine system. Estuar. Coast. Shelf Sci. 86, 237-246. doi: 10.1016/j.ecss.2009.11.019

Pereira, T. J., Silva, G., Costa, M. J., and Costa, J. L. (2011). Life strategies of Halobatrachus didactylus (Bloch and Schneider, 1801) in the Tagus estuary: comparison among different morphotypes. Estuar. Coast. Shelf Sci. 93, 328-335. doi: $10.1016 /$ j.ecss.2011.04.013

Post, D. M. (2002). Using stable isotopes to estimate trophic position: models, methods, and assumptions. Ecology 83, 703-718. doi: 10.1890/0012-9658(2002) 083[0703:USITET]2.0.CO;2

Reis-Santos, P., Tanner, S. E., França, S., Vasconcelos, R. P., Gillanders, B. M., and Cabral, H. N. (2015). Connectivity within estuaries: an otolith chemistry and muscle stable isotope approach. Ocean Coast. Manag. 118, 51-59. doi: 10.1016/j.ocecoaman.2015.04.012

Reis-Santos, P., Tanner, S. E., Vasconcelos, R. P., Elsdon, T. S., Cabral, H. N., and Gillanders, B. M. (2013). Connectivity between estuarine and coastal fish populations: contributions of estuaries are not consistent over time. Mar. Ecol. Progr. Ser. 491, 177-186. doi: 10.3354/meps 10458

Reis-Santos, P., Vasconcelos, R. P., Tanner, S. E., Fonseca, V. F., Cabral, H. N., and Gillanders, B. M. (2018). Extrinsic and intrinsic factors shape the ability of using otolith chemistry to characterize estuarine environmental histories. Mar. Environ. Res. 140, 332-341. doi: 10.1016/j.marenvres.2018.06.002

Ridgway, J., and Shimmield, G. (2002). Estuaries as repositories of historical contamination and their impact on shelf seas. Estuar. Coast. Shelf Sci. 55, 903-928. doi: 10.1006/ecss.2002.1035

Rochet, M. (2000). A comparative approach to life-history strategies and tactics among four orders of teleost fish. ICES J. Mar. Sci. 57, 228-239. doi: 10.1006/ jmsc.2000.0641

Scaps, P. (2002). A review of the biology, ecology and potential use of the common ragworm Hediste diversicolor (O.F.Müller) (Annelida: Polychaeta). Hydrobiologia 470, 203-218. doi: 10.1023/a:1015681605656

Schartup, A. T., Ndu, U., Balcom, P. H., Mason, R. P., and Sunderland, E. M. (2015). Contrasting effects of marine and terrestrially derived dissolved organic matter on mercury speciation and bioavailability in seawater. Environ. Sci. Technol. 49, 5965-5972. doi: 10.1021/es506274x

Tanner, S. E., Reis-Santos, P., Vasconcelos, R. P., Fonseca, V. F., França, S., Cabral, H. N., et al. (2013). Does otolith geochemistry record ambient environmental conditions in a temperate tidal estuary? J. Exp. Mar. Biol. Ecol. 441, 7-15. doi: 10.1016/j.jembe.2013.01.009

Thorman, S., and Wiederholm, A.-M. (1986). Food, habitat and time niches in a coastal fish species assemblage in a brackish water bay in the Bothnian Sea, Sweden. J. Exp. Mar. Biol. Ecol. 95, 67-86. doi: 10.1016/0022-0981(86) 90088-2

Válega, M., Abreu, S., Pato, P., Rocha, L., Gomes, A. R., Pereira, M. E., et al. (2006). Determination of organic mercury in biota, plants and contaminated sediments using a thermal atomic absorption spectrometry technique. Water Air Soil Pollut. 174, 223-234. doi: 10.1007/s11270-0069100-7

Vasconcelos, R. P., Reis-Santos, P., Fonseca, V., Maia, A., Ruano, M., Franca, S., et al. (2007). Assessing anthropogenic pressures on estuarine fish nurseries along the Portuguese coast: a multi-metric index and conceptual approach. Sci. Total Environ. 374, 199-215. doi: 10.1016/j.scitotenv.2006.12.048

Vasconcelos, R. P., Reis-Santos, P., Maia, A., Fonseca, V., França, S., Wouters, N., et al. (2010). Nursery use patterns of commercially important marine fish species in estuarine systems along the Portuguese coast. Estuar. Coast. Shelf Sci. 86, 613-624. doi: 10.1016/j.ecss.2009.11.029 
Vaz, N., and Dias, J. M. (2014). Residual currents and transport pathways in the Tagus estuary, Portugal: the role of freshwater discharge and wind. J. Coast. Res. 70, 610-615. doi: 10.2112/si70-103.1

Conflict of Interest Statement: The authors declare that the research was conducted in the absence of any commercial or financial relationships that could be construed as a potential conflict of interest.
Copyright () 2019 Fonseca, França, Duarte, Caçador, Cabral, Mieiro, Coelho, Pereira and Reis-Santos. This is an open-access article distributed under the terms of the Creative Commons Attribution License (CC BY). The use, distribution or reproduction in other forums is permitted, provided the original author(s) and the copyright owner(s) are credited and that the original publication in this journal is cited, in accordance with accepted academic practice. No use, distribution or reproduction is permitted which does not comply with these terms. 